\title{
The Western Balkans Stock Exchanges Unification in Response to the Pandemic Crisis
}

Received: 20.01.2021

Available online: 29.09 .2021

Vilizar Chupetlovski", Peter Chobanov", Yavor Rusinov"**

\section{Abstract}

Western Balkans is a term describing Eastern European countries that include North Macedonia, Montenegro, Serbia, Albania, and Kosovo. The report puts Bulgaria next to the Western Balkan countries. The pandemic situation since the beginning of 2020 creates a need for fresh capital in all national economies. During the pandemic, non-standard decisions should be made in favor local economic agents to support and standardize economic processes. The pandemic necessitates the creation of alternative financing for economies. The Balkan Stock Exchange project faces the opportunity to be implemented through the Committee of the European Parliament. In stock market history a merger is not a precedent. The first steps were in 2001, by Euronext. The Balkan Stock Exchange problems are mainly in the legislation and the tax treatment of income from financial instruments and dividends. The biggest positive for countries will be if, owing to the Balkan Stock Exchange, the possibility of remote access and investment keeps economies running. Through funding from an effective Balkan stock exchange, economic life should continue, albeit transformed into a remote one, so that the pandemic can be overcome with the least possible damage and without complete closure of the economies.

Keywords: Western Balkans, Stock Exchanges, Pandemic Crisis

JEL: G01; G15

\section{Introduction}

$\Delta s$ a region, the Western Balkans Arefers to Eastern European countries that include North Macedonia, Montenegro, Serbia, Albania, and Kosovo. Within the countries of the Western Balkans, we include Bulgaria for the purpose of development. The macroeconomic development of Eastern European countries Bulgaria, Albania, Montenegro, Serbia, and North Macedonia, sharply and drastically decreased after the large-scale political changes after the beginning of the 1990s. Periods of the rise and recession alternate. The main drivers of the economy in a positive direction are the individual economic potentials of each

\footnotetext{
* PhD student, Department of Finance, University of National and World Economy, Sofia

** Assoc Prof. Dr., Department of Finance, University of National and World Economy, Sofia

${ }^{\star \star *} \mathrm{PhD}$, Department of Computer Sciences, University of Library Studies and Information Technologies, Sofia
} 


\section{Articles}

country. As a result, each of them is in a different economic stage. Standard potential and opportunities for growth lie in the attempts of individual countries to develop their capital markets. So far, none of the individual stock exchange markets has a clear dominant role.

During the first stage of the pandemic, when individual countries in a moment of panic restricted social activities and substantial public gatherings, this harmed the basic expectations for markets' future development and was immediately reflected in market prices. In March 2020, world stock exchange markets lost a considerable part of the prices traded securities. This trend is relevant for all exchange operators. In this respect, all agents suffered losses because large economic entities such as banks, insurance companies, investment funds and pension companies lost the value of their assets within a few days without hedge or exchanged their positions. From the perspective of the above-described economic entities' capital adequacy, huge problems arise due to an unpredictable change in the value of the assets owned. Based on the owned assets, mainly securities, the specific economic entities can attract additional funds in debt. When assets' value as collateral falls below specific debt levels, they may be instantly due. In such a situation the bankruptcy of one or more economic funds, banks, or pension companies could mean substantial economic crises, similar to those of 2008, by successively suspending the activities of economically related entities. The average prices on the financial markets gradually returned to pre-crisis levels by the end of 2020. Specific economic operators have the opportunity to attract additional funds in the form of debt. This piece of research examines the opportunities for the unification of the capital markets of Bulgaria, Serbia,
North Macedonia, Montenegro, Albania and Kosovo as an anti-crisis measure after the economic consequences of the Covid-19 pandemic. The common stock exchange market aims to increase the invested funds in the whole region of the Western Balkans and their future effective use in its economic development.

The research object is the countries of the Western Balkans and their stock exchange markets and the impact of the pandemic on them.

The research topic is gross domestic product (GDP), GDP per capita, market capitalization, turnover, and the number of transactions on the capital markets in Bulgaria, Serbia, North Macedonia, Montenegro, and normative pan-European documents.

The study aims to expose the economic consequences of the Covid-19 pandemic and considers a hypothesis for a unified stock exchange in the Balkans.

\section{IMPACT OF THE COVID-19 PANDEMIC}

At the beginning of 2020 , the world was hit by an unpredictable crisis caused by a new strain of coronavirus - severe acute respiratory syndrome coronavirus 2 (SARSCoV-2), known as Covid-19. The only proven means of protection is social distancing. Economic entities restructure their activities, transferring them remotely so that they can save their lives and health. Some countries impose restrictions even on the movement of their citizens. The extraordinary and unpredictable consequences of the global pandemic, which forces individual countries to limit individuals' contact and keep social distance to limit the health consequences, creates economic problems for all countries. Such problems include reducing productivity 


\section{Articles}

and the production of certain goods and services that are not essential. These economic consequences have a multiplier effect, reducing total tax revenues in individual countries. There is also an increase in social spending in the countries caused by rising unemployment and increased health costs for treating people infected with Covid-19.

In this respect, the unified Balkan's Stock Exchange project in question seems optimistic. In exchange market history, such a merger is not a precedent. The first steps were taken in 2001 by unifying the Amsterdam, Brussels, Paris, and later on, the Lisbon stock exchange, which adopted the name Euronext. Euronext
The Western Balkans Stock Exchanges Unification in

Response to the Pandemic Crisis

is the first merger model of this kind. In recent years there has been a growing interest in merging two of the largest European stock exchanges - the London stock exchange and the Deutsche stock exchange.

European countries have led to disorganization in almost all economic sectors by imposing epidemiological measures, including financial instruments' operations. One of the first victims of economic change is the capital markets. Figure 1 presents the monthly values for 2020. The volume of transactions carried out on the Euronext is the largest stock exchange in Europe with a market capitalization of EUR 4.4 trillion.

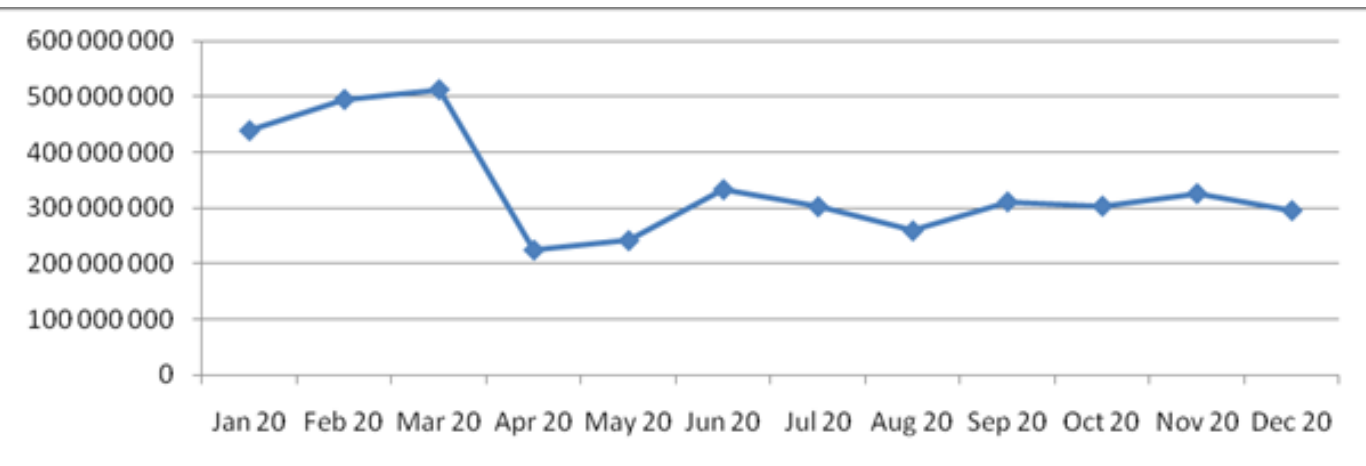

Figure.1 Monthly value of volume -Euronext

In the first two months of 2020 markets were moving at a standard growth rate generated in the last three years. In January and February the markets did not take into consideration the situation in China, particularly the city of Wuhan, which is generally seen as the primary source of infection by Covid-19. Until the beginning of March the markets did not show concern about the new virus, and it was in the middle of March that European countries led by Germany and France began to announce lockdown. This process passed through all countries in Europe and was immediately reflected in the prices of the traded financial instruments. In Figure 1 until March 2020 the trading volume was positive and by the end of March and April there was a historical decline by $56 \%$ in the prices of financial instruments. This decline had a negative effect on the total volume of transactions. States allowed local economic agents to continue working, albeit with specific distancing and disinfection measures, which slow down or limit production and logistics processes. Despite the pandemic's continuing expansion, markets regained investor confidence by restoring financial instruments' prices. By the end of 2020 there was volatility in the volumes of traded financial instruments, which can be attributed to several peaks in Covid-19 infection 


\section{Articles}

rate and subsequent lockdown measures. The downward trend in the prices and volumes of traded financial instruments is also valid for the stock exchanges in Montenegro, Serbia,
North Macedonia and Bulgaria. Due to their inferior liquidity, the markets covered by this study cannot show statistically significant deviations, as is the case with Euronext.

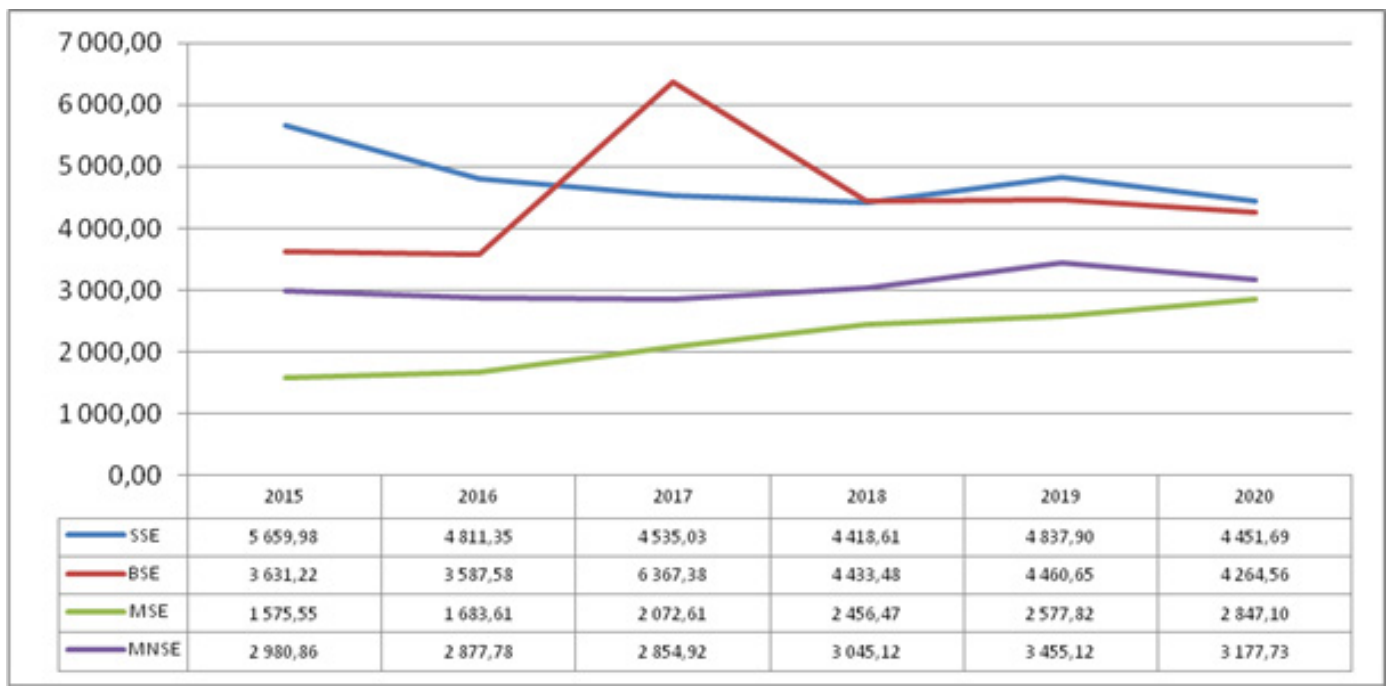

Figure.2 Market Capitalization- Serbia, Bulgaria, North Macedonia, Montenegro

When observing the average monthly market capitalization in millions of euros on the stock exchanges in the Western Balkans, Figure 2 shows a decrease in 2020 compared to 2019. The most significant decline is seen in Serbia and Montenegro's stock exchanges, with a decrease of $8 \%$ per year. The stock exchange market capitalization in Bulgaria decreased by $4 \%$, while only the North Macedonian Stock Exchange showed an increase of $10 \%$ in the capitalization for the period.

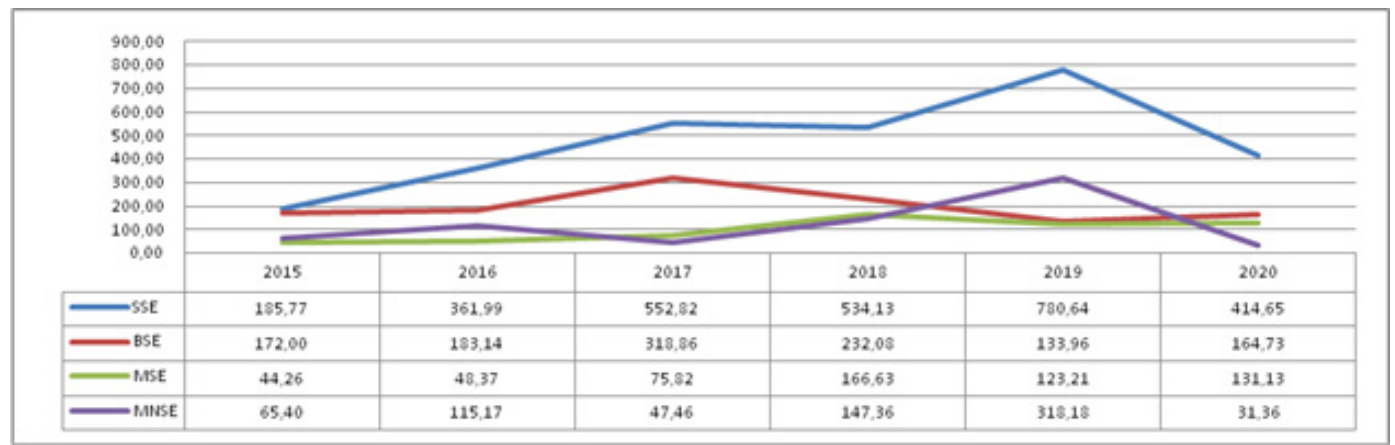

Figure 3. Turnover - Serbia, Bulgaria, North Macedonia, Montenegro

Figure 3 shows the turnover on stock exchanges from the Western Balkans (in mln euro) for the period 2015 - 2020. There is an apparent decrease by $90 \%$ of the trading volumes on the Montenegrin stock exchange, followed by a decrease of $47 \%$ in the turnover of Serbia's stock exchange for 2019 - 2020. An increase is observed in the stock exchange in 


\section{Articles}

North Macedonia by $6 \%$. Despite the pandemic situation, the Bulgarian stock exchange market rose by $23 \%$ for $2019-2020$.

The market capitalization and turnover for each of the exchanges show an evident change attributed to the global pandemic of Covid-19. During crises or pandemics, nonstandard decisions must be made in favor of local economic agents to support and standardize economic processes, not only in the Balkan region.

The pandemic situation since the beginning of 2020 creates a need for fresh capital in all national economies. The possibility to unite the different exchanges will boost the efficiency of trading and increase liquidity. It will create easy access for small businesses short of funds and international investors looking for an alternative to the bank's low-interest rates. Hence connecting investors and companies will make it possible to finance small and medium-sized companies, which are the pandemic's most prominent victims.

The establishment of a unified market will raise funds for large-scale infrastructure projects requiring capital unattainable for
The Western Balkans Stock Exchanges Unification in

Response to the Pandemic Crisis

individual stock exchanges. Due to the individual countries' inability to independently develop their economy's specific niche, the need for large-scale development projects arises. At the heart of this is the unification of individual economies through a single investment point and capital investment.

Given the poor economic performance ${ }^{1}$ caused by the Covid-19 pandemic and the need to attract significant foreign investments, the creation of the unified Balkan's Stock Exchange would allow the region to accumulate investments unattainable by any country.

\section{STOCK EXCHANGE MARKETS ANALYSIS BY GROSS DOMESTIC PRODUCT}

A well-developed capital market from an economic point of view increases the possibility of individual economies' development and prosperity. Figure 4 presents the studied relationship between the market capitalization of the stock exchanges and GDP at the national level for Bulgaria, Serbia, North Macedonia and Montenegro Figure 4

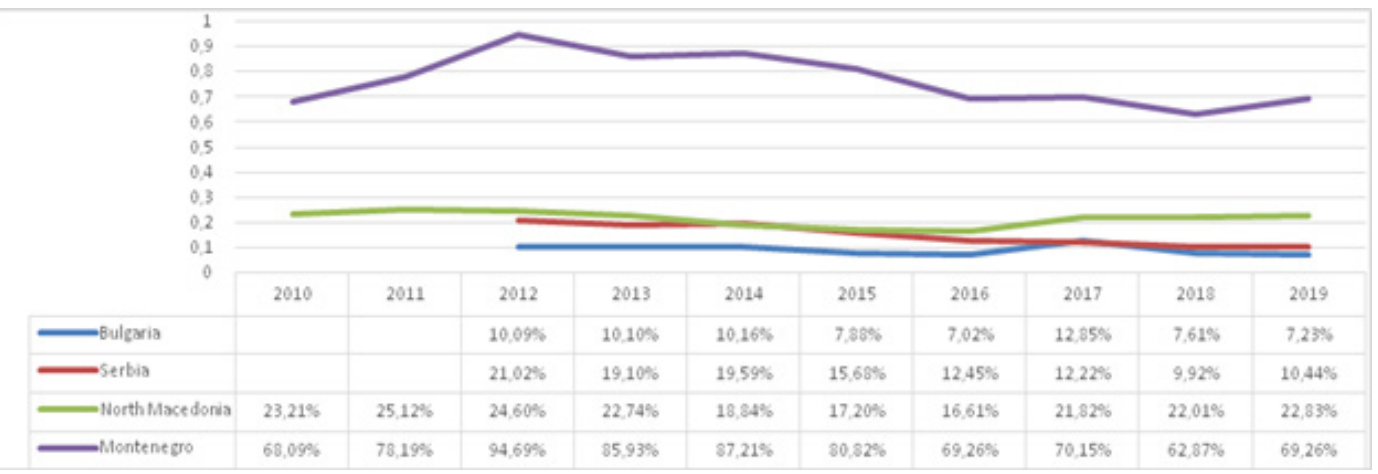

Figure 4. Percentage of market capitalization in relation to the Gross Domestic Product Serbia, Bulgaria, North Macedonia, Montenegro

1 Economic Research Institute, 2020. Macroeconomic Implications of the Fight against COVID-19: EXPRESS EVALUATIONS, CONCLUSIONS AND FORECASTS AS OF 12.04.2020. 


\section{Articles}

For the study, public data are used on the Gross Domestic Product of the individual countries published on the World Bank website ${ }^{2}$ and respectively the market capitalization of each of the exchanges for the period from 2012 to 2019 inclusive, as well as published individual data on the official websites of each exchange.

If the calculation result is greater than $100 \%$, it is interpreted that the market is overvalued. The value of the indicator around $50 \%$ is interpreted as an undervalued market. If the valuation ratio is between 50 and $75 \%$, the market is slightly undervalued.

Albania has a functioning stock exchange for the period, but it does not have statistically significant indicators for transactions in public companies' shares, only government bond issues are listed and traded. In Kosovo, there was no functioning stock exchange operator for the period under review, nor is there any at present. Due to both countries' specifics, they will not be included in the study, given the lack of statistically significant data. As a result of the analysis, it has been established that, of all countries under review, only Montenegro falls within the limits of a slightly undervalued market by investors, as it is the only country that has a result of $50 \%$ of its Gross Domestic Product. The volatility in the indicator for Montenegro is due to the capitalization, while the gross product maintains a growth rate throughout the period considered.

The second country surveyed, North Macedonia, falls under the underestimated range, maintaining an average of about $20 \%$ of its Gross Domestic Product for the entire period. The market capitalization in Northern Macedonia remains stable. The indicator is mainly due to GDP, which has a constant growth rate except for 2017.

During the period under review, Serbia remained within a highly undervalued market with an average value of around $15.05 \%$, and the Serbian market operator showed an apparent decrease in the indicator throughout the period. The main criterion for reduction is market capitalization, which fails to compensate for the country's sustainable growth of GDP.

Bulgaria occupies the last place among the surveyed objects, showing about 9\% substantial underestimation of the market. The country's GDP is constantly growing, while the market capitalization is moving in the opposite direction.

Based on the indicator for assessing the market capitalization about the gross domestic product, it can be concluded that with the merger of the considered stock exchange operators, the possibility for investor confidence is high due to the substantial underestimation of the current markets. From the investors' point of view, such a market is attractive because of the prerequisites for future development. In the case of combined market operators, setting a target of at least $50 \%$ of the countries' GDP would increase each exchange market in the range between $200 \%$ and $400 \%$, which is in the case of a realistic option. If an optimistic option is targeted and values around $75 \%$ of the countries' GDP, it would increase each exchange market in the range from $375 \%$ to $600 \%$.

Objectively speaking, none of the countries relies on their capital markets for economic development. Theoretically, the formula for

\footnotetext{
2 World Bank, GDP, World Bank national accounts data, and OECD National Accounts data files
} 


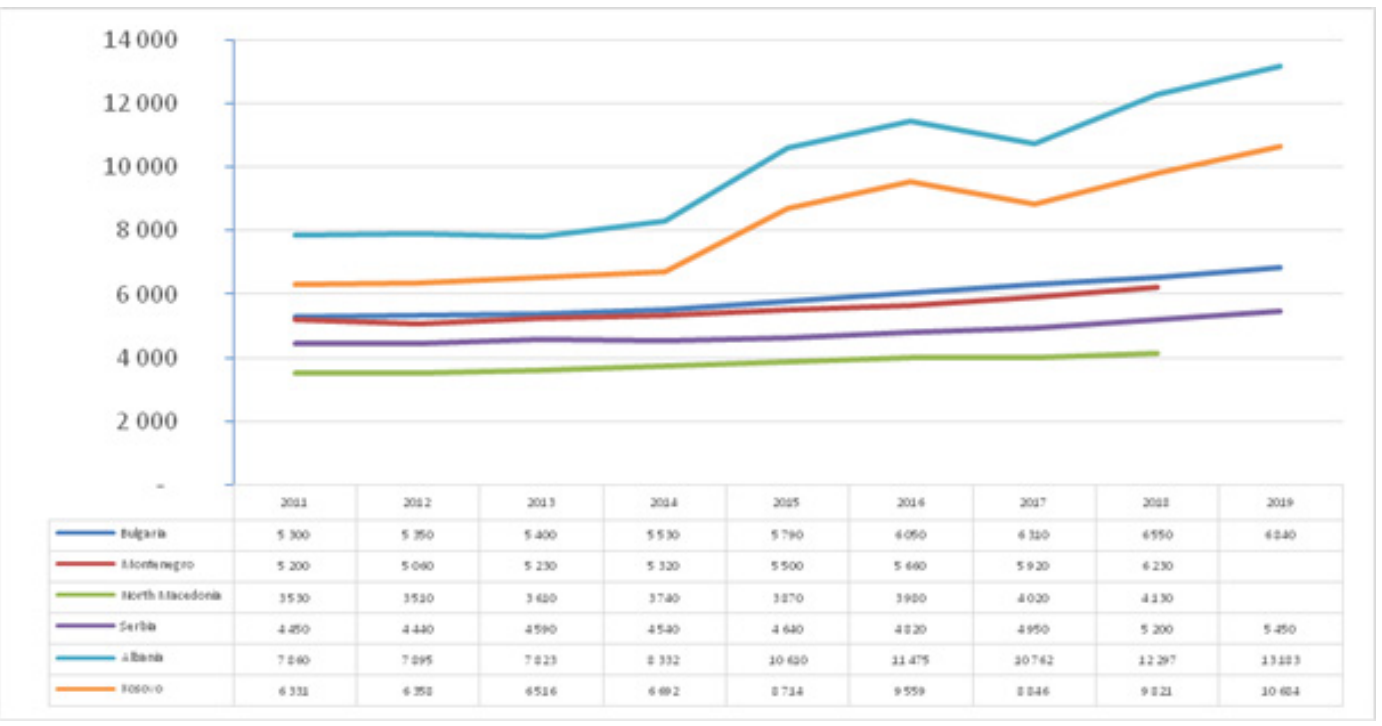

Figure.5 Gross domestic product per capita- Bulgaria, Serbia, North Macedonia, Montenegro, Albania, Kosovo

economic development goes through raising external investments for the region.

According to World Bank $^{3}$ data from 2013 , the growth of market capitalization by every 10 percent relative to Real GDP leads to an increase in the per-capita GDP by approximately 2250 euros.

Two options for increasing the market capitalization are considered. The first option is realistic. The purpose is to reach a market capitalization of up to $50 \%$ of the real GDP for a separate stock market.The second option is seen as optimistic for the region, aiming to reach $75 \%$ market capitalization relative to GDP at the national level.

Figure 5 shows the GDP per capita for the period 2011 - 2019 in millions of euros.

Figure 6 shows the percentage increase in GDP per capita, with a realistic option and reaching $50 \%$ capitalization in the local market relative to GDP.
Figure 7 shows the percentage increase in GDP per capita in a realistic option and reaching $75 \%$ capitalization in the local market relative to GDP.

From the considered two options for increasing the market capitalization and the hypothesis for increasing the GDP per capita of the countries, it is assumed that Montenegro will have an increase in GDP per capita only in the last three years of the optimistic model aimed at reaching $75 \%$ of market capitalization to GDP. Albania and Kosovo are reported only in terms of GDP. The model is limited due to the lack of effectively functioning capital markets and insufficient data on their market capitalization. They have the same curves in the basic information on GDP and the subsequent consideration of increasing capitalization options. This shows the same movement in GDP per capita for the two countries.

3 World Bank and DRC (Development Research Center of the State Council, the People's Republic of China), 2014. Urban China: Toward Efficient, Inclusive, and Sustainable Urbanization. Washington, DC: World Bank. 


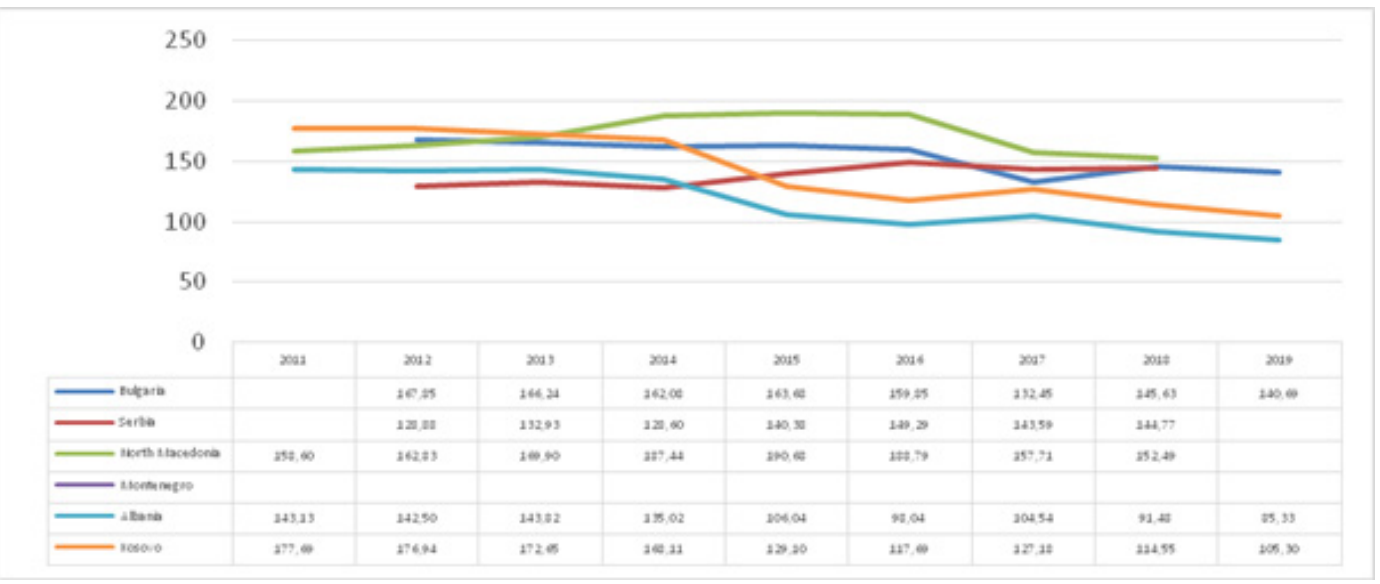

Figure 6 Percentage growth through a realistic model applied to Gross Domestic Product per capita- Bulgaria, Serbia, North Macedonia, Montenegro, Albania, Kosovo.

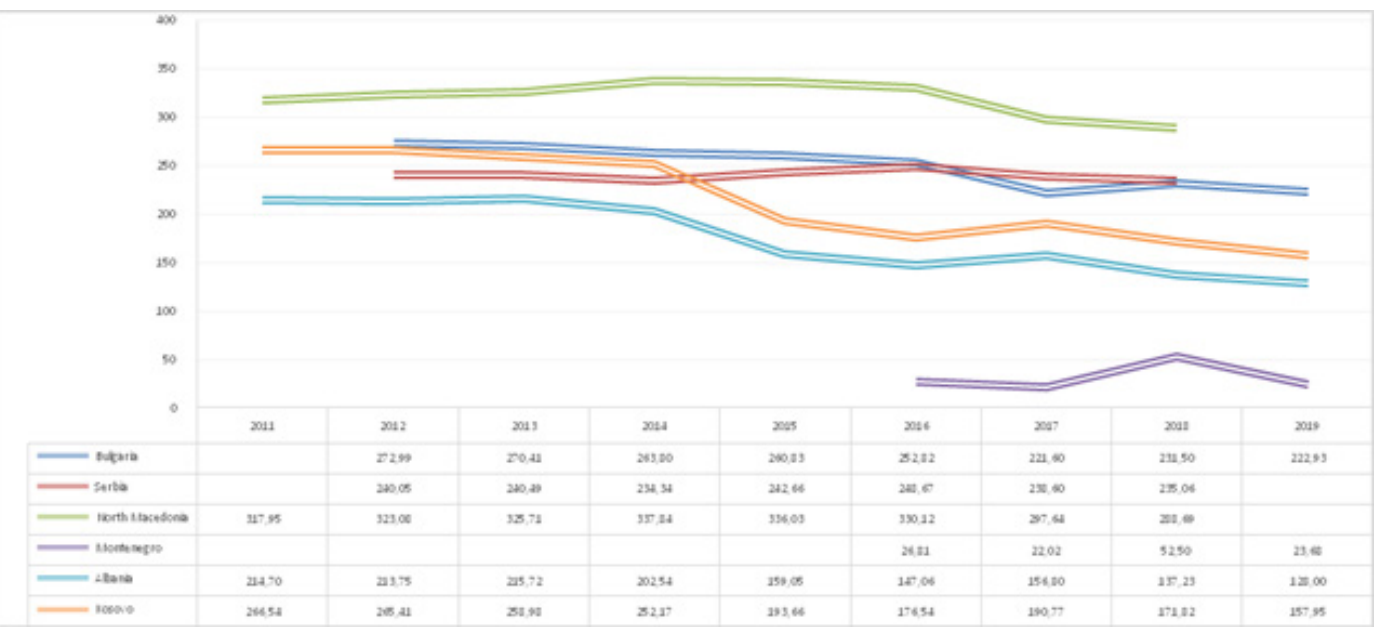

Figure 7 Percentage growth through an optimistic model applied to Gross Domestic Product per capita- Bulgaria, Serbia, North Macedonia, Montenegro, Albania, Kosovo.

With the increase in GDP per capita in both models, the graphs for North Macedonia show the highest percentage change, reaching a peak in 2015. Bulgaria maintains a relatively constant rate of increase throughout the period, except for a marked decline in 2017. Serbia is the only example of an increase without a subsequent decline in the principle in question.
The charts for an optimistic and realistic option, show the percentage increase in GDP per capita. They are characterized by inverse dependence on the graphic of GDP development. For this reason, the graphs are used to visually illustrate the data and the opportunities for individual countries for future development, resulting from the efficient use of capital markets, other things being equal. Effective use of capital markets would be 


\section{Articles}

possible by combining them into a single structure that will receive higher liquidity.

\section{RELATIONS BETWEEN THE EUROPEAN UNION AND THE WESTERN BALKANS}

None of the Western Balkan countries is part of the European Union family member due to economic, political, legislative, and institutional problems. For individual countries, joining Europe's economic family is a goal. The European Union's desire for the accession of member states is also not lacking. For both countries, there are many positives from future EU accession.

As an economic entity, the EU requires specific parameters for the admission of countries to the European family. They are known as the Copenhagen criteria. Including:

- Stable institutions that guarantee democracy, the rule of law, human rights, and respect for and protection of minorities

- A functioning market economy and capacity to deal with competition and market forces in the EU

- Ability to take on and effectively fulfill the obligations arising from membership, including adherence to the objectives of political, economic and monetary union.

In the last $3-4^{4}$ years ${ }^{5}$, various joint projects aimed at integrating the countries are being worked on from the Western Balkans. Each of the coutries is at a different stage related to accession, Albania has the status of a candidate for EU membership, but negotiations for its accession have not yet begun. North Macedonia is a potential member; the country has historical problems with neighboring countries that currently do not allow it to
The Western Balkans Stock Exchanges Unification in

Response to the Pandemic Crisis

continue membership negotiations. Kosovo is holding talks to apply for EU membership. Serbia and Montenegro are closest to joining the European Community - they are opening negotiation chapters and are seen as potential members around 2025.

Bulgaria has been a full member of the European Union since 2007, and as such Bulgaria must require the application of European regulations in the unified market, such as compliance with Regulation 596 ${ }^{6}$, commission regulation (EU) No 1799/2006, Regulation 809, and others. In this way, it can serve as an intermediary in the relations between the EU and the Western Balkan countries.

\section{UNIFIED CAPITAL MARKET PROJECT UNDER THE NAME BALKAN STOCK EXCHANGE}

The project for Balkan Stock Exchange finds its opportunity for realization through the committee of the European Parliament, which is a report from 2020. draws attention to the Capital Markets Union.

The report addresses critical issues for both the EU and non-EU countries. Initially and most importantly, we pay attention to the abbreviation Union of Capital Markets. This union will create an entirely new ideology and working principle for all exchange participants. The idea of a capital markets union was mainly born with a view to recovery from the pandemic crisis in which the world found itself as an alternative to short-term bank financing and low-yield bank deposits.

The pandemic necessitates the creation of alternative financing for economies, and in particular for small businesses, which in times

\footnotetext{
4 Declaration of the European Union and Western Balkans partners, 2018. Sofia

5 Declaration of the European Union and Western Balkans partners, 2020. Zagreb

6 European Parliament, REGULATION (EU) No 596/2014. Official Journal of the European Union
} 


\section{Articles}

of economic turmoil feel the need for additional financing, which in most cases is crucial for companies. With reduced cash inflows from reduced consumption, companies need financing. Additional funding can take the form of increased equity. Banking institutions cannot attract such financing. This reveals the need for an efficient market to finance the costs of the companies' main activity. Given the scale of individual countries and the small volumes of stock exchanges in the Balkans - Serbia, North Macedonia, Montenegro, Bulgaria, and their stock exchange operators, the capitalization currently has the status of emerging markets - external professional investors are repelled. The local investors have already invested in some of their available investment opportunities, making it challenging to implement a new initial public offering of new shares.

The initial public offering of shares is a fundamental process for the efficiency of the capital markets. With its practical and successful implementation, new opportunities are created for public companies and investors. After the first distribution, the issuer begins to develop his business due to the newly attracted capital and the prerequisites for creating added value to already attracted equity. Value added is the main element that brings profitability to investors. The more added value the public company accumulates, the more liquid and valuable the share becomes. Before the Covid-19 crisis, a small number of companies made an initial public offering. During the pandemic, there was no initial public offering. With the creation of the Balkan's Stock Exchange, the unified market will provide a broader range of shares to a larger circle of investors. On the part of public companies, this maximizes the chance to complete the issue. On the part of investors, it creates a broader range of opportunities for diversification. Preconditions are being created for more initial public offerings listed on the stock exchanges. From this, first follows an increase in fee income, which the stock exchange will accumulate, and subsequently an increase in the capitalization of stock exchanges and, accordingly, investor interest. Capitalization is one of the exchange market scale indicators and investors want to invest in markets with higher capitalization.

The common capital market requires a common technical infrastructure, both for the conclusion of transactions and for their closing. Each country in the Western Balkans is building and using its technological solution to achieve a working platform to help meet the demand and supply of financial instruments and a platform for finalizing transactions with the final transfer of financial instruments' ownership.

The trading and clearing and settlement systems operating in the Republic of Bulgaria ${ }^{7}$ allow their expansion to a scale that will cover all issuers from the Western Balkans and all investors' countries. The trading system - Xetra T7 - is well known and known to global investors. Developed and maintained by Deutsche Börse $A G$, and the platform also operates in other European markets. The technical infrastructure created and maintained by Central Depository AD for the completion of the transactions concluded by investors allows the implementation of both essential services according to Section $A$ of the Annex to Regulation (EU)

\footnotetext{
7 Deyan, I., 2018. Development of the Bulgarian Capital Market After Accession of Bulgaria to the European Union. European The Membership of Bulgaria in the European Union: Ten Years Later. Print-ISBN-13: 978-619-232-111-6. pp 137-146
} 


\section{Articles}

No 909/2014 and the implementation of ancillary services according to Section B of the Annex to Regulation (EU) No 909/2014. As early as 2018, the state regulator issued a license for these activities.

The Montenegro Stock Exchange as a trading platform uses BTS trading system version 2.6, designed by the IT company Novita and the Ljubljana Stock Exchange. BTS system is a Windows-based trading system designed for small and medium capital markets. It provides high performance on very modest hardware. The order processing speed is 400 orders per second on standard Intel-based hardware and a latency time of $10 \mathrm{~ms}$. BTS includes the implementation of the FIX 4.4 standard. FIX Gateway enables FIX clients to connect to the trading system via the standard FIX 4.4 protocol. Standards SSL is used to ensure encrypted communications. In a pandemic where everyone seeks to limit the spread of Covid-19, the common entrance to the unified capital market is the most appropriate solution for group protection. If the investor maintains several different platforms for access to each market and pays additional transaction costs for access to a foreign market, in the event of a pandemic situation, it is very likely that, in order to limit costs, the number of markets available should be reduced. Hence a shared trading platform could stop the outflow of investors. For exchange operators, it will be easier to maintain a common platform instead of five different systems. Their technical teams will help each other and be interchangeable in the event of a technical problem. A single platform will provide the same functionality for all markets, and there will be no need for investors to study different types of orders.
The Western Balkans Stock Exchanges Unification in

Response to the Pandemic Crisis

The unified platform will allow for a rapid change in the political and economic situation. The investor will be able to change the market without unnecessary additional actions, and to choose a market with lower political or economic risk. According to their risk profile, the countries in the region have individual characteristics that would help investors choose a market ${ }^{8}$. Investors who segment their portfolios in individual industries would have a better choice than issuers in separate industries, for example, in pharmacy, telecommunications and others.

\section{INFLUENCE OF THE COVID-19 CRISIS ON INVESTORS}

After the onset of the pandemic in early 2020 and the subsequent lockdown of most legal entities, investors lowered their expectations of traded companies' prices except for pharmaceutical and medical companies. The decline in the confidence of some companies has reduced their price. The falling price has had adverse effects on large professional investors, such as pension and insurance companies, which have traditionally invested huge sums of money in exchangetraded instruments. The indirect effect for professional investors forces them to invest in riskier assets in order to maintain their projected returns. The specific returns for pension companies are even defined as part of their core business. With almost all prices falling, the portfolios of these companies fall without being able to hedge effectively. This problem is also solved in the unified Balkan's Stock Exchange.

A unified and stable market will allow professional investors not to move their capital between the separate stock

8 Stoikova, A., 2018. Market Dynamics of Stock Exchanges of South East Europe - Efficiency and Harmonizationh. Economic and social alternatives 


\section{Articles}

exchanges but only change the company or industry remaining inside the exchange. This will presumably prevent sharp fluctuations in prices caused by the scale of traded volumes. Pension companies will not be forced to invest in high-risk securities due to the larger scale of the unified market's investment opportunities.

Professional investors also include companies whose key operating activity is asset securitization. During the Covid-19 pandemic, companies with specific securitization activities could have a substantial positive effect. Their activity will allow mainly the banking institutions to release funds with which to finance companies that do not have the opportunity and capacity to obtain financing from the capital market. Securitization without an efficient market is a precarious business. Furthermore, in the presence of securitization companies investing in receivables, the potential for a faster exit from the crisis is more significant. Factoring allows long-term investors to invest in undervalued assets that have secured collateral. For banks, fresh capital will allow interest rates to be maintained without being forced to reduce lending.

Individual investors will enjoy a significant advantage from the union of capital markets. Due to the need to create uniform standards for public companies, such as disclosing financial information and uniform regulatory requirements, the possibility for easier orientation of non-professional investors will increase the opportunities for effective investment. When entering a long-term position by non-professional investors, they can adopt strategies that will bring them a safe return in the long run and be a complementary part of their retirement income. This active position of non-professional investors will balance the expectations for funds paid by pension companies and be part of the increased liquidity for the Union of Capital Market.

The Balkan stock exchange will have another positive effect on individuals obtaining a satisfactory and acceptable return on exchange-traded instruments instead of bank deposits, which though nominally positive at present, in effect offer negative interest rates.

The effect on the countries' national budgets during a pandemic is a reduction in tax revenues and the need to increase social investment. Countries and individual ministries are proceeded to attract debt capital, the scale of which can only be provided by capital markets. Objectively and without the Balkan stock exchange, countries will be able to accumulate the desired funds, but with the current Balkan stock exchange, the funds and subsequently the yield will have the status of domestic debt, in the long run, and there will be no future impoverishment of the population in addition to risk-free investment.

\section{EFFECTS AND PROBLEMS FROM THE ESTABLISHMENT OF A UNIFIED STOCK EXCHANGE IN THE BALKANS}

Bulgaria, North Macedonia, Serbia, and Montenegro have stock exchange operators developing in terms of scale, efficiency, modernization, and profit. None of the countries described above can compete with medium-sized European stock exchange operators like Greece or Poland. Through the pooling of professional human resources, the Balkan stock exchange allows standard capitalization, reduced costs, and increased revenues to approach and become an effectively competitive market, attracting more and more large-scale investor potential and increasing profitability. Accordingly, small local entrepreneurs are increasing in scale to become international economic entities, and 


\section{Articles}

in the long term, leaders in their activities. In order to facilitate the trade relations between the individual exchange operators, the unified stock exchange also needs a single currency to be used by all participants in the trading processes. Each of the countries participating in this study uses its currency, which is an obstacle to the easy and fast transfer of financial instruments for cash.

Not all countries have the opportunity to use the Euro as a national currency. Due to the specific requirements of Article 140 of The treaty on the functioning of the European Union of the above countries, only Bulgaria has the opportunity to introduce the Euro as a national currency in a short time.

In the case of different currency units for the individual participants, it will be necessary to monitor the individual currency units' exchange rates daily. In addition to fees for the trade transaction itself, separate currency conversion fees will be provided. To facilitate the process, the most effective option for the currency used is the Euro, and the Republic of Bulgaria is in The Exchange Rate Mechanism (ERM) II $^{9}$, which is an indicator of the country's proximity to the official introduction of the Euro as the official currency. Montenegro and Kosovo have unilaterally introduced the use of the Euro as their official currency. Serbia, North Macedonia, and Albania have their currencies. However, given future goals and prospects for accession as full members of the European Union, the Euro for payments in financial instrument transactions is an acceptable option for individual countries and a practical option for a unified market.

During the economic crisis, large infrastructure projects are considered an anti-crisis measure. However, in the absence
The Western Balkans Stock Exchanges Unification in

Response to the Pandemic Crisis

of adequate tax revenues and increased government debt levels, infrastructure projects must search for alternative financing given their public function, it is not easy to find investors. The effect of this opportunity is to relieve the state budgets from significant funds and create an opportunity for investors to benefit from a secure and long-term investment. Under the existing system and individual exchanges, such public-private projects are impossible due to the lack of investor potential for investment on such a scale. In addition, a private investor could enter into a direct contract with the country. The prospect is that such projects will be aimed at many individual investors through the unified stock exchange they will have access to.

The Balkan stock exchange is an opportunity for individuals and legal entities to specialize in the best activities and constantly upgrade them. The income they will receive will be invested in other areas and industries in which investors are interested. In this way, the increase of the quality of all goods and services will be stimulated and the financing in the branches external to the investor. This would have the role of income hedging, and the subsequent effect would be to increase the liquidity, turnover, capitalization, efficiency, and profit of the stock exchange operator.

The biggest positive for countries will be if, owing to the Balkan stock exchange, the possibility of remote access and investment keeps economies running. Through funding from an effective Balkan stock exchange, economic life should continue, albeit transformed into a remote one, so that the pandemic can be overcome, with the least possible damage and without complete closure of the economies.

${ }^{9}$ European Commission, ERM II - the EU's Exchange Rate Mechanism 


\section{Articles}

The Balkan stock exchange problems are mainly in the legislation and the tax treatment of income from financial instruments and dividends. Individual countries such as Bulgaria, Serbia, North Macedonia, Montenegro, Albania, and Kosovo have their own national regulations and do not have many contact points. However, the Balkan stock exchange creates favorable preconditions for the countries due to its requirement to have European regulation. Upon reaching an agreement on adopting European standards and regulations, a modern and institutional appearance and a high level of security in the Balkan stock exchange will be achieved with high confidence. The complementary effect will be for countries aiming to join the EU. When adopting uniform standards and European norms, the candidate countries will show readiness to adopt the other reforms required by them.

It must be borne in mind that capital markets are one of the most highly regulated economic sectors, and presumably, there should be no possibility for abuse investors have complete confidence. With good regulation, the Balkan stock exchange has a good chance of becoming a leading stock exchange operator. Given the regulations, uniform standards must be created so that information is disseminated relatively effectively and quickly. This condition mainly benefits non-professional investors, but it will also be a relief for professionals. Uniform standards for the dissemination of information will also create relief for companies, as they will have a specific form to fill in and publish.

Along with reporting standards, there should be clear and accurate identification and classification of companies. This classification will be done by industry, company size, risk, solvency and efficiency and should be done professionally by newlyestablished local rating agencies, or by attracting proven international ones. The rating agencies will create categories to which the companies will be assigned, their scale, risk structure, and specifics. This activity can also be assigned to the operator himself. At present stock exchanges largely perform such segmentation.

Based on segmentation, investors will be able to act more quickly, with less cost and time to choose a familiar industry and a particular company, and depending on the rating implement its investment plan. The last stage, analyzing the financial data, should be the role taken up by individual investors. Those who cannot rely correctly on financial data will trust professional consultants or mutual funds. At present investors rarely choose external territories for investment because there are income taxes in the issuer's country and in the investor's country.

\section{Conclusion}

The effects on individual stock exchanges caused by the Covid-19 pandemic in 2020 are drastically reduced primary financial instruments and traded volumes. The decline is due to the mechanisms imposed on people in Europe to curb the spread of the Covid-19 pandemic. The creation of vaccines and the immunization of the population help relieve public measures and hence bring about the normalization of the production, logistics and business processes in Europe and the world. The Western Balkans are not isolated from the spread of the Covid-19 pandemic. After health problems are solved, there will arise economic problems and decreased values of the major macroeconomic indicators.

The macroeconomic development in the Balkans is a key factor for Europe's future. 


\section{Articles}

In order to support the states, a mechanism for the development of investments in public companies is being considered, which in turn will become the driving engine of the national economies and the region as a whole. The examined indicators of local stock exchanges from which financial resources should be drawn, expose the lack of the capacity to serve as the backbone of the countries' economic prosperity. Due to this circumstance, it is necessary to take non-standard decisions, including creating a unified capital market. Its primary role will be to bring together the potential of the involved stock exchanges and to multiply the future results. The Balkan stock exchange will play a central economic role for the whole of Europe as it will accumulate and redistribute investment funds through its effective structure in individual countries.

The Balkan stock exchange is a complex solution for the fastest market-efficient option for the Western Balkans' future development.

\section{References}

Beckers, S. E., 1999. Investment Implications of a Single European Capital Market. The Journal of Portfolio Management, 25, 3, p. 9-17;

Communication from the commission to the European Parliament. A Capital Markets Union for people and businesses - new action plan. European Commission, 2020. COM (2020) 590, Available URL : (https://eur-lex.europa. eu/resource.html? uri=cellar:61042990fe46-11ea-b44f-01aa75ed71a1.0001.02/ DOC_2\&format=PDF) [30.03.2021]

Communication from the commission to the European Parliament. A credible enlargement perspective for and enhanced EU engagement with the Western Balkans. European Commission, 2018. COM(2018)65. Available URL: (https://ec.europa.eu/commission/sites/ beta-political/files/annex-communication-
The Western Balkans Stock Exchanges Unification in

Response to the Pandemic Crisis

credible-enlargement-perspective-westernbalkans_en.pdf) [30.03.2021]

Declaration of the European Union and Western Balkans partners, 2018. Sofia

Available URL: (https://www.consilium.europa. eu/media/34776/sofia-declaration_en.pdf) [30.03.2021]

Declaration of the European Union and Western Balkans partners, 2020. Zagreb Available URL: https://www.consilium.europa. eu/media/43776/zagreb-declarationen-06052020.pdf [30.03.2021]

Deyan, I., 2018. Development of the Bulgarian Capital Market After Accession of Bulgaria to the European Union. European The Membership of Bulgaria in the European Union: Ten Years Later. Print-ISBN-13: 978-619-232-111-6. pp 137-146. Available URL: (https://www.ceeol.com/search/bookdetail?id=915420 ) [30.03.2021]

Economic Research Institute, 2020. Macroeconomic Implications of the Fight against COVID-19: EXPRESS EVALUATIONS, CONCLUSIONS AND FORECASTS AS OF 12.04.2020. Bulgarian Academy of Sciences. Available URL: (https://www.iki.bas.bg/files/ covid_effects.pdf) [30.03.2021]

Euronext, Euronext Fact Book 2020. Available URL: (https://live.euronext.com/resources/ statistics ) [30.03.2021]

European Commission, ERM II - the EU's Exchange Rate Mechanism. Available URL: (https://ec.europa.eu/info/business-economyeuro/euro-area/introducing-euro/adoptionfixed-euro-conversion-rate/erm-ii-eusexchange-rate-mechanism_en) [30.03.2021]

European Council, Council of the European Union, 2020. EU enlargement, Available URL: (https://www.consilium.europa.eu/en/policies/ enlargement/) [30.03.2021]

European Parliament, REGULATION (EU) No $596 / 2014$. Official Journal of the European Union. Available URL: ( https://eur-lex.europa. 


\section{Articles}

e u / l e g a I - c o n t e n t / b g / TXT/?uri=CELEX\%3A32014R0596 [30.03.2021]

European Parliament, REGULATION (EU) No 809/2014. Official Journal of the European Union. Available URL: (https://eur-lex.europa. e u / l e g a I - c o n t e n t / B G / TXT/?uri=CELEX\%3A32014R0809 [30.03.2021]

European Parliament, REGULATION (EU) 2017/1799. Official Journal of the European Union. Available URL: (https://eur-lex.europa. eu/eli/reg_del/2017/1799/oj/bul ) [30.03.2021]

Eurostat, GDP and main components. Available URL: (https://ec.europa.eu/eurostat/ databrowser/view/nama_10_gdp/default/ table?lang=en) [30.03.2021]

Fikri, Kenan; Zhu, T. Juni., 2015. City Analytics : Competitive Cities for Jobs and Growth, Companion Paper 1. World Bank, Washington, DC. () World Bank. Available URL: (https://openknowledge.worldbank.org/ handle/10986/23569 ) License: CC BY 3.0 IGO. [30.03.2021]

Green Paper. Building a capital Markets Union, European commission, 2015. Available URL: (https://eur-lex.europa.eu/legal-content/ EN/TXT/?uri =celex\%3A52015DC0063 [30.03.2021]

Horvath, R., and D. Petrovski, 2013. International Stock market integration: Central and South Eastern Europe compared. IOS Working Paper No.317

International Monetary Fund (2020). Fiscal Monitor, April 2020. Chapter 1: Policies to Support People During the COVID-19 Pandemic. ISSN: 2219-276X.

Ivanov, I., B. Lomev, and B. Bogdanova, 2012. Investigation of the market efficiency of emerging stock markets in the East-European region. International Journal of Applied Operational Research, 2(2), pp. 13-24.
Kenourgios, D., and A. Samitas, 2011. Equity market integration in emerging Balkan markets. Research in International Business and Finance, 25(3), pp. 296-307.

Luchov, G., Nancheva, I., 2008. Development of the capital market in Bulgaria, management and sustainable development., pp. 23-25, 3-4/2008(21). Available URL: (http://oldweb.Itu. bg/jmsd/files/articles/21/21-03_G_Lachov_I_ Nencheva.pdf ) [30.03.2021]

Lucian Albu, Radu Lupu and Adrian Cantemir Calin, (2014). A Nonlinear Model to Estimate the Long Term Correlation between Market Capitalization and GDP per capita in Eastern EU Countries. Working Papers of Institute for Economic Forecasting. Institute for Economic Forecasting. 141115. Institute for economic forecasting. Available URL : (https://www. researchgate.net/publication/277422518_A_ nonlinear_model_to_estimate_the_long_ term_correlation_between_market_ capitalization_and_GDP_per_capita_in_ eastern_EU_countries ) [30.03.2021]

Nenkova, P., Angelov, A., 2020. Assessment of the Fiscal Stances of the Balkan States. Economic Archive, (4). pp. 14-34. Available URL: (https://dlib.uni-svishtov.bg/ handle/10610/4410) [30.03.2021]

Nikolova, I., 2020. Societal global risks and future of world economy in pandemic.

Sofia, New Bulgarian Universit. Available URL (http://eprints.nbu.bg/4310/) [30.03.2021]

Stoikova, A., 2018. Market Dynamics of Stock Exchanges of South East Europe - Efficiency and Harmonizationh. Economic and social alternatives. Available URL: (https://www.unwe. bg/uploads/Alternatives/6_Alternativi $\% 20$ br2_2018_BG.pdf ) [30.03.2021]

Tsenkov, V., 2015. Crisis influences between developed and developing capital markets the case of central and eastern European countries. Economic Studies, 3, pp. 71-108 


\section{Articles}

World Bank and DRC (Development Research Center of the State Council, the People's Republic of China), 2014. Urban China: Toward Efficient, Inclusive, and Sustainable Urbanization. Washington, DC: World Bank. Available URL: (https://www.worldbank.org/ content/dam/Worldbank/document/EAP/ China/WEB-Urban-China.pdf ) [30.03.2021]

World Bank, GDP, World Bank national accounts data, and OECD National Accounts data files. Available URL: (https://data. worldbank.org/indicator/NY.GDP.MKTP. CD?end=2019\&name_desc $=$ true\&start $=2010$ ) [30.03.2021]
The Western Balkans Stock Exchanges Unification in

Response to the Pandemic Crisis

World Bank, GDP per capita, PPP. International Comparison Program, World Bank, World Development Indicators database, World Bank | Eurostat-OECD PPP Programme. Available URL: (https://data.worldbank.org/ indicator/NY.GDP.PCAP.PP.CD?locations=AL ) [30.03.2021]

World Health Organisation, 2018. Managing epidemics: Key facts about major deadly diseases. Geneva. ISBN 978-92-4-156553-0. Available URL: (https://www.who.int/ emergencies/diseases/managing-epidemics/ en/) [30.03.2021] 